\title{
Red cell alloimmunization and autoantibodies in Egyptian transfusion-dependent thalassaemia patients
}

\author{
Azza Mohamed Ahmed², Nehal Salah Hasan², Shadia Hassan Ragab², Sonia Adolf Habib², \\ Nahed Abdelmonem Emara², Azza Ahmed Aly²
}

${ }^{1}$ Department of Paediatrics, National Research Centre, Cairo, Egypt

2Department of Clinical and Chemical Pathology, National Research Centre, Cairo, Egypt

Submitted: 2 April 2010

Accepted: 18 June 2010

Arch Med Sci 2010; 6, 4: 592-598

DOI: 10.5114 /aoms.2010.14473

Copyright (c) 2010 Termedia \& Banach

\author{
Corresponding author: \\ Nehal Salah Hasan \\ Department of Clinical \\ and Chemical Pathology \\ National Research Centre (NRC) \\ Cairo, 12622 Egypt \\ Phone: +20233607 15 \\ Fax: +2023370931 \\ E-mail: nemyb@hotmail.com
}

\begin{abstract}
Introduction: The objective of this study was to explore the frequency of red cell alloantibodies and autoantibodies among $\beta$-thalassaemia patients who received regular transfusions.

Material and methods: This study included 501 patients with $\beta$-thalassaemia. This work planned to study the presence of alloantibodies and autoantibodies to different red cell antigens in multitransfused thalassaemia patients using the ID. Card micro typing system.

Results: Of a total of $501 \beta$-thalassaemia patients included in the study, $11.3 \%$ of patients developed alloantibodies; $9.7 \%$ of these alloantibodies were clinically significant. The most common alloantibodies were anti-K, anti-E and anti-C. The rate of incidence of these alloantibodies was 3.9\%, 3.3\% and $1.7 \%$ respectively. Autoantibodies occurred in $28.8 \%$ of the patients and $22.1 \%$ of these antibodies were typed IgG. There was a significant association between splenectomy with alloimmunization and autoantibody formation ( $p=0.03, p=0.001$ respectively). There was no significant association between alloantibody, autoantibody formation and number of transfused packed red cells.

Conclusions: Alloimmunization to minor erythrocyte antigens and erythrocyte autoantibodies of variable clinical significance are frequent findings in transfused $\beta$-thalassaemia patients. There is an association between absence of the spleen and the presence of alloimmunization and autoantibody formation.
\end{abstract}

Key words: $\beta$-thalassaemia, alloimmunization, autoantibodies.

\section{Introduction}

Thalassaemia is among the most common genetic disorders worldwide, particularly in the Mediterranean region, Africa, the Middle East and Southeast Asia [1]. Thalassaemia is a hereditary anaemia resulting from defects in haemoglobin production [2]. $\beta$-Thalassaemia, which is caused by a decrease in the production of $\beta$ globin chains, affects multiple organs and is associated with considerable morbidity and mortality [3]. Accordingly, lifelong care is required and financial expenditures for proper treatment are substantial [4]. The recommended treatment for thalassaemia major involves regular blood transfusions, usually administered every 2 to 5 weeks to maintain a pre-transfusion haemoglobin level above $9-10.5 \mathrm{~g} / \mathrm{dl}$. One of the complications of blood transfusion is the formation of alloantibodies and autoantibodies against red blood cell (RBC) antigens [5]. 
Results from a number of studies have demonstrated various frequencies and percentages of alloantibody and autoantibody formation in multi-transfused patients [6].

Some alloantibodies may cause haemolytic transfusion reactions, which limits the possibility of safe transfusion, while others are clinically insignificant. Red cell autoantibodies appear less frequently but can result in haemolysis and difficulty in blood cross-matching [7].

Antibodies must be identified in the recipient's serum before each transfusion so that compatible blood can be provided. The causes of alloimmunization in thalassaemia patients are not fully understood. However, data suggest that the recipient's immune status, absence of spleen and difference in the red cell phenotype between donors and recipients are likely to contribute further to the phenomenon [8].

The aim of this study was to explore the frequency of alloimmunization and erythrocyte autoantibodies among $\beta$-thalassaemia patients receiving regular transfusions and the factors that might contribute to their development, and to investigate the RBC phenotype of Egyptians.

\section{Material and methods}

This study was conducted over a 2-year period from January 2006 to December 2007 at the Paediatric Haematology Unit of the National Research Centre (NRC). The study was approved by the Ethics Committee of the NRC. Written consent was provided for each patient.

A total of $501 \beta$-thalassaemia patients who received regular blood transfusions were included in the study. They were 389 patients with $\beta$-thalassaemia major (228 males and 161 females) aged 2-24 years, 59 patients with $\beta$-thalassaemia intermedia (24 males and 35 females) aged 4-26 years and 53 patients with sickle cell- $\beta$ thalassaemia syndrome ( 27 males and 26 females) aged 4-19 years.

The diagnosis of thalassaemia was confirmed by standard haemoglobin electrophoresis and measurements of $\mathrm{Hb} A, A_{2}$ and $\mathrm{F}$.

Clinical transfusion records of $501 \beta$-thalassaemia patients who fulfilled the criteria were analysed for ethnic background; age at start of transfusion and number of transfused packed red cells (the majority of our patients had been exposed to non-leukodepleted blood for a long time before introduction of the universal leukodepletion protocol for thalassaemia patients). All patients in our unit received fully blood matched for only $A B O$ and $\mathrm{Rh}(\mathrm{D})$ antigens. Presence of the spleen was also recorded. There were no available data about the time from start of transfusion to antibody formation. Patients received supportive treatment in the form of folic acid ( $5 \mathrm{mg} /$ day, oral), calcium (40-80 mg/day, oral) and vitamin D (400 IU/day, oral).

Patients with connective tissue disease or autoimmune disease, or receiving immunosuppressive or immunomodulatory drugs were excluded from the study.

\section{Laboratory investigation}

The practical part of this work aimed to study the presence of alloantibodies and autoantibodies to different red cell antigens in multitransfused thalassaemia patients using the ID - Card micro typing system (Gel tear, Switzerland). Dia Cell I, II and III were used to screen for the presence of red cell alloantibodies and the Dia Panel to identify these alloantibodies.

All pre-transfused patients were routinely tested for $\mathrm{ABO}$ and $\mathrm{Rh} \mathrm{D}$ antigen.

Screening of the sera for erythrocyte antibodies and identification tests: the idea of this test was to detect alloimmune antibodies formed against any $\mathrm{RBC}$ antigen in the tested sera; this was done with two different tests: screening and identification tests.

The antibody screening test was done with a combination of 3 sets of commercial group 0 red blood cells which have been typed for clinically significant antigens as well as rare antigens. These 3 sets are known as Dia - cell I, II, III.

Dia cell I contains the following antigens:

D, C, e, C ${ }^{\omega}, k, k p^{b}, J s^{b}, F^{a}, J K^{b}, F y^{b}, L^{b}, P, N, S, L u^{b}$ and $x g^{a}$.

Dia cell II contains the following antigens:

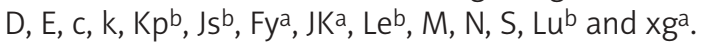
Dia cell III contains the following antigens:

C, E, k, kp ${ }^{b}, J^{a}$, Fy $y^{b}, J K^{b}$, Le ${ }^{a}, P, N, S, L^{b}$ and $x g^{a}$.

Positive sera (with Dia cell I or II or III or all) were examined by an identification test using the Dia panel, which consists of 11 different group $O$ red cells: k, C, E, JKb, Lea kp $^{\mathrm{a}}, \mathrm{M}, \mathrm{I}, \mathrm{Fy}^{\mathrm{b}}, \mathrm{N}, \mathrm{S}$.

\section{Statistical analysis}

Statistical Package for the Social Sciences (SPSS) program version 9 was used for analysis of data. Data were summarized as mean \pm SD and percentage.

Comparison of multiple subgroups was done using one-way ANOVA.

Fisher's Exact Test Calculator for a $2 \times 2$ contingency table was used.

Analysis of two independent variables was done by using a non-parametric test (Mann-Whitney $\mathrm{U}$ test).

In all tests, the value of $p$ was considered significant if $>0.05$.

\section{Results}

Characteristics of $\beta$-thalassaemia patients are summarized in Table I. There was a highly signi- 
ficant difference between and within the 3 groups regarding age, start of transfusion and rate of transfusion $(p=0.001)$. Also, Table I shows the percentage of our patients that had splenectomy.

Table II demonstrates the frequency of red blood cell alloantibody formation in $\beta$-thalassaemia patients. Of the total 501 multi-transfused $\beta$-thalassaemia patients 57 patients (11.3\%) developed alloantibodies. Forty-nine $(9.7 \%)$ of these alloantibodies were clinically significant (i.e. capable of causing haemolytic transfusion reaction or haemolytic disease of newborn).

The most common alloantibodies were anti-K (Kell system), anti-E and anti-C (Rhesus system). The incidence of these alloantibodies was 20 (3.9\%), $17(3.3 \%)$ and $9(1.7 \%)$ respectively of the total 501 patients with $\beta$-thalassaemia.

Furthermore, comparison between groups of $\beta$-thalassaemia patients revealed a highly significant association between $\beta$-thalassaemia major compared to sickle cell- $\beta$-thalassaemia syndrome, and $\beta$-thalassaemia intermedia compared to sickle cell- $\beta$-thalassaemia $(p=0.001)$ regarding both the total of clinically significant patients and total alloantibodies.

Table III demonstrates the frequency of red blood cell autoantibodies in $\beta$-thalassaemia patients. This study revealed that 145 (28.8\%) of the total 501 patients with $\beta$-thalassaemia had autoantibodies, and 111 (22.1\%) of them were typed immunoglobulin G (IgG). Immunoglobulin G was detected in 99 (25.4\%) of 389 patients with $\beta$-thalassaemia major, 4 (6.7\%) of 59 patients with $\beta$-thalassaemia intermedia and 8 (15\%) of 53 patients with sickle cell- $\beta$-thalassaemia syndrome.

Also, regarding total autoantibodies Table III shows a highly significant association between groups of $\beta$-thalassaemia major compared to $\beta$-thalassaemia intermedia, and $\beta$-thalassaemia intermedia compared to sickle cell- $\beta$-thalassaemia syndrome ( $p=0.001, p=0.04$ respectively).

Table IV represents the association of splenectomy with alloantibodies and autoantibodies in $\beta$-thalassaemia patients. Among the splenectomized group, 30 patients with $\beta$-thalassaemia major had alloantibodies and 123 patients with $\beta$-thalassaemia major had autoantibodies, while in the non-splenectomized group none of them had alloantibodies or autoantibodies ( $p=0.001)$.

Overall, of the $233 \beta$-thalassaemia patients with splenectomy, 35 (15\%) patients became alloimmunized and of the 269 patients without splenectomy, 22 patients (8.1\%) became alloimmunized $(p=0.03)$. Also, of the 233 patients with splenectomy, 140 patients (60\%) developed autoantibodies and of 269 patients without splenectomy, 5 patients (1.8\%) developed autoantibodies ( $p=0.001)$.

Analysis using the Mann-Whitney test shows that there was no significant association between alloantibody or autoantibody formation and the number of transfused packed red cells ( $p=0.5$, $p=0.9$ respectively). Also, there was no significant association between alloantibody or autoantibody formation and age at start of transfusion $(p=0.3$, $p=0.5$ respectively) (Table $\mathrm{V}$ ).

\section{Discussion}

Only a few studies in the world have investigated the frequency and causes of alloimmunization and autoimmunization [9]. In the present study we examined these elements and defined the common RBC phenotypes among Egyptians which have not been previously described.

In this study the frequency of alloimmunization was $11.3 \%$ in transfusion-dependent thalassaemia patients. Previous data on presumed homogeneous populations in Italy showed an overall low rate (10\%) of alloimmunization [10]. This is consistent

Table I. Characteristics of $\beta$-thalassaemia patients

\begin{tabular}{|c|c|c|c|c|}
\hline Items & $\begin{array}{l}\beta \text {-Thalassaemia } \\
\text { major }(n=389)\end{array}$ & $\begin{array}{c}\beta \text {-Thalassaemia } \\
\text { intermedia }(n=59)\end{array}$ & $\begin{array}{l}\text { Sickle cell- } \beta \\
\text { thalassaemia }(n=53)\end{array}$ & $\begin{array}{l}\text { Value } \\
\text { of } p\end{array}$ \\
\hline Age [years] & $(2-24)^{\star}$ & $(4-26)^{\star}$ & $(4-19)^{\star}$ & 0.001 \\
\hline Mean \pm SD & $9.29 \pm 3.98$ & $12.73 \pm 4.58$ & $10.49 \pm 2.97$ & \\
\hline $\begin{array}{l}\text { Start of transfusion } \\
\text { [months] }\end{array}$ & $(6-30)^{\star}$ & $(24-72)^{*}$ & $(10-48)^{\star}$ & 0.001 \\
\hline Mean \pm SD & $13.37 \pm 4.21$ & $43.02 \pm 7.73$ & $29.26 \pm 12.31$ & \\
\hline $\begin{array}{l}\text { Rate of transfusion } \\
\text { [units/year] }\end{array}$ & $(4-12)^{*}$ & $(3-12)^{*}$ & $(2-12)^{*}$ & 0.001 \\
\hline Mean \pm SD & $9.43 \pm 2.41$ & $5.05 \pm 1.58$ & $6.46 \pm 2.19$ & \\
\hline \multicolumn{5}{|l|}{ Splenectomy: } \\
\hline - Yes & $214(55 \%)$ & 11 (18.6\%) & $10(18.9 \%)$ & \\
\hline - No & 175 (45\%) & 48 (81.4\%) & 43 (81.1\%) & \\
\hline
\end{tabular}

*minimum to maximum, SD - standard deviation, $p$ value $<0.05$ is significant, $p$ value $<0.01$ is highly significant 
Table II. Frequency of red blood cell alloantibody formation in $\beta$-thalassaemia patients

\begin{tabular}{|c|c|c|c|c|c|}
\hline Alloantibody & $\begin{array}{l}\beta \text {-Thalassaemia } \\
\text { major }(n=389)\end{array}$ & $\begin{array}{c}\beta \text {-Thalassaemia } \\
\text { intermedia }(n=59)\end{array}$ & $\begin{array}{l}\text { Sickle cell- } \beta \\
\text { thalassaemia }(n=53)\end{array}$ & $\begin{array}{c}\text { Total } \\
(n=501)\end{array}$ & $\begin{array}{l}\text { Value } \\
\text { of } p\end{array}$ \\
\hline Anti-K* & 14 (3.5\%) & $2(3.3 \%)$ & $4(7.5 \%)$ & 20 (3.9\%) & $\begin{array}{l}p_{1}=1 \\
p_{2}=0.2 \\
p_{3}=0.4\end{array}$ \\
\hline Anti-C $C^{*}$ & $6(1.5 \%)$ & - & $3(5.6 \%)$ & 9 (1.7\%) & $\begin{array}{l}p_{1}=0.5 \\
p_{2}=0.08 \\
p_{3}=0.1\end{array}$ \\
\hline Anti-E* & $8(2 \%)$ & $2(3.3 \%)$ & 7 (13.2\%) & 17 (3.3\%) & $\begin{array}{l}p_{1}=0.6 \\
p_{2}=0.01 \\
p_{3}=0.09\end{array}$ \\
\hline Anti-Fya & $2(0.5 \%)$ & - & $4(7.5 \%)$ & $6(1.2 \%)$ & $\begin{array}{l}p_{1}=1 \\
p_{2}=0.002 \\
p_{3}=0.05\end{array}$ \\
\hline Anti-M & $1(0.2 \%)$ & - & $1(1.8 \%)$ & $2(0.4 \%)$ & $\begin{array}{l}p_{1}=1 \\
p_{2}=0.2 \\
p_{3}=0.2\end{array}$ \\
\hline Anti-Kpa* & $2(0.5 \%)$ & - & $1(1.8 \%)$ & $3(0.6 \%)$ & $\begin{array}{l}p_{1}=1 \\
p_{2}=0.01 \\
p_{3}=0.1\end{array}$ \\
\hline Total & 33 (8.4\%) & $4(6.7 \%)$ & 20 (37.7\%) & 57 (11.3\%) & $\begin{array}{l}p_{1}=0.8 \\
p_{2}=0.001 \\
p_{3}=0.001\end{array}$ \\
\hline $\begin{array}{l}\text { Total of clinically } \\
\text { significant } \\
\text { patients }\end{array}$ & 30 (7.7\%) & $4(6.7 \%)$ & 15 (28.3\%) & 49 (9.7\%) & $\begin{array}{l}p_{1}=1 \\
p_{2}=0.001 \\
p_{3}=0.01\end{array}$ \\
\hline
\end{tabular}

*Indicates clinically significant, $p_{1}$ - comparison of $\beta$-thalassaemia major vs. $\beta$-thalassaemia intermedia, $p_{2}-$ comparison of $\beta$-thalassaemia major vs. sickle cell- $\beta$-thalassaemia, $p_{3}$ - comparison of $\beta$-thalassaemia intermedia vs. sickle cell- $\beta$-thalassaemia, $p<0.05$ is significant, $p<0.01$ is highly significant

Table III. Frequency of red blood cell autoantibodies in $\beta$-thalassaemia patients

\begin{tabular}{|lccccc|}
\hline Alloantibody & $\begin{array}{c}\beta \text {-Thalassaemia } \\
\text { major }(n=389)\end{array}$ & $\begin{array}{c}\beta \text {-Thalassaemia } \\
\text { intermedia }(n=59)\end{array}$ & $\begin{array}{c}\text { Sickle cell- } \beta \\
\text { thalassaemia }(n=53)\end{array}$ & $\begin{array}{c}\text { Total } \\
(n=501)\end{array}$ & $\begin{array}{l}\text { Value } \\
\text { of } p\end{array}$ \\
\hline $\operatorname{lgG}$ & $99(25.4 \%)$ & $4(6.7 \%)$ & $8(15 \%)$ & $111(22.1 \%)$ & $\begin{array}{l}p_{1}=0.005 \\
p_{2}=0.23 \\
p_{3}=0.23\end{array}$ \\
\hline $\operatorname{lgM}$ & $27(6.9 \%)$ & $1(1.6 \%)$ & $6(11.3 \%)$ & $34(6.8 \%)$ & $\begin{array}{l}p_{1}=0.23 \\
p_{2}=0.16 \\
p_{3}=0.06\end{array}$ \\
& & & & $145(28.9 \%)$ & $\begin{array}{l}p_{1}=0.001 \\
p_{2}=0.6 \\
p_{3}=0.04\end{array}$ \\
\hline Total & $126(32.3 \%)$ & $5(8.4 \%)$ & $14(26.4 \%)$ & & \\
& & & & \\
\end{tabular}

Ig-immunoglobulin, $p_{1}$ - comparison of $\beta$-thalassaemia major vs. $\beta$-thalassaemia intermedia, $p_{2}-$ comparison of $\beta$-thalassaemia major vs. sickle cell- $\beta$-thalassaemia, $p_{3}$ - comparison of $\beta$-thalassaemia intermedia vs. sickle cell- $\beta$-thalassaemia, $p<0.05$ is significant, $p<0.01$ is highly significant

with our study. Similarly, Ho et al. [7] in Hong Kong found that the alloimmunization rate in thalassaemia patients was $7.4 \%$. Other studies by Noor Haslina et al. [8] and Karimi et al. [9] reported that the incidence of alloimmunization in Malay and Shiraz, Southern Iran, was $8.6 \%$ and $5.3 \%$ respectively.

Our low alloimmunization rate in this study and other similar studies can probably be explained by the similarity in the ethnicity between patients and donors. All of our alloimmunized patients were Egyptian and most of our blood donors were also Egyptian. In Hong Kong the majority of immunized patients were Southern Chinese and all the blood donors were predominantly of the same ethnic origin. A lower rate of alloimmunization in their study was explained by their access to phenotypically matched donors in Hong Kong [7].

On the other hand, the alloimmunization rate in two studies done in Greece [11] and Kuwait [6] 
Table IV. Relationship of splenectomy with alloantibodies and autoantibodies in $\beta$-thalassaemia patients

\begin{tabular}{|lccc|}
\hline Items & $\begin{array}{c}\text { With splenectomy } \\
(n=232)\end{array}$ & $\begin{array}{c}\text { Without splenectomy } \\
(n=269)\end{array}$ & $\begin{array}{c}\text { Value } \\
\text { of } p\end{array}$ \\
\hline Alloantibody & $30(13 \%)$ & - & 0.001 \\
\hline$\beta$-Thalassaemia major & $2(0.8 \%)$ & $3(1.1 \%)$ & 1 \\
\hline$\beta$-Thalassaemia intermedia & $3(1.2 \%)$ & $19(7 \%)$ & 0.003 \\
\hline Sickle cell- $\beta$-thalassaemia & $35(15 \%)$ & $22(8.1 \%)$ & 0.03 \\
\hline Total & & & 0.001 \\
\hline Autoantibody & $123(53 \%)$ & - & 0.01 \\
\hline$\beta$-Thalassaemia major & $8(3.4 \%)$ & $1(0.3 \%)$ & 0.1 \\
\hline$\beta$-Thalassaemia intermedia & $9(3.9 \%)$ & $4(1.5 \%)$ & 0.001 \\
\hline Sickle cell- $\beta$-thalassaemia & $140(60.3 \%)$ & $5(1.8 \%)$ & \\
\hline Total & & & \\
\hline
\end{tabular}

Table V. Relationship of red cell alloantibodies and autoantibodies with number of transfused packed red cells and age at start of transfusion

\begin{tabular}{|lcc|}
\hline Item & $\begin{array}{c}\text { Alloantibodies } \\
\text { (Value of } p \text { ) }\end{array}$ & $\begin{array}{c}\text { Autoantibodies } \\
\text { (Value of } p \text { ) }\end{array}$ \\
\hline $\begin{array}{l}\text { Number of transfused } \\
\text { packed red cells } \\
\text { [units/year] }\end{array}$ & 0.5 & 0.9 \\
\hline $\begin{array}{l}\text { Age at start of } \\
\text { transfusion [year] }\end{array}$ & 0.3 & 0.5 \\
\hline
\end{tabular}

Value of $p>0.5$ is not significant

was $22 \%$ and $30 \%$ respectively. The higher alloimmunization rate in these two studies was probably due to the heterogeneity of the populations living in Greece and Kuwait and mismatched RBC phenotypes between donors and recipients.

Also, other studies by Sylvia et al. [12] and Gader et al. [13] found a high alloimmunization rate of $20.8 \%$ and $22.06 \%$ among Asians and in Saudi Arabia because the majority of patients received multi-ethnic blood.

In the current study anti-K (Kell system) was seen most frequently, followed by anti-E and anti-C (Rhesus system), which are all potentially haemolytic antibodies. All of our patients received compatible blood for ABO, Rh D.

In an Italian study [14] alloantibodies were confined to the common antigens of the Kell, Rhesus and Kidd systems. This is similar to our study. Also, in studies from Iran and Kuwait, Karimi et al. [9] and Ameen et al. [6] found that the most common alloantibodies were anti-Rh C, E and D. Meanwhile, several studies have shown that anti-E antibodies were the most prevalent alloantibodies among transfusion-dependent thalassaemia patients [7, 8, 12]. Spanos et al. [15] demonstrated that for prevention of alloimmunization, transfusion of blood matched for Rh and $\mathrm{K}$ antigens resulted in a significant difference in the alloimmunization rate.
The factors for alloimmunization are complex and involve at least 3 main contributing elements: the RBC antigenic difference between the blood donor and the recipient, the recipient's immune status, and the immunomodulatory effect of the allogenic blood transfusion on the recipient's immune system [12]. A low rate of alloimmunization may be expected when there is homogeneity of RBC antigens between the blood providers and recipients [16]. Other factors beyond the antigenic discrepancy, in particular the immune system, are undoubtedly involved. An overall normal $\mathrm{CD}_{4}: \mathrm{CD}_{8}$ ratio was shown in thalassaemia patients transfused with post-storage leukocyte-depleted blood [17]. However, a marked absolute lymphocytosis mostly due to an increase in B lymphocytes predominantly in splenectomized patients was reported with the use of both nonleukoreduced and leukoreduced blood [18]. The lymphocytosis is accompanied by an increase in serum immunoglobulins, immune complexes, and cells bearing surface immunoglobulins which are the result of the immunomodulatory effect of blood elements, absence of spleen and recipient immune status $[19,20]$. The majority of patients in the present study had long-term exposure to nonleukodepleted blood.

In this study the incidence of autoantibodies was $28.8 \%$. Our data were similar to an Asian study where $25 \%$ of their thalassaemia patients developed autoantibodies [12]. Also a Kuwait study observed that $11 \%$ of their patients developed autoantibodies [6].

However, a study in Iran found that the rate of autoantibodies was $1.4 \%$ [9]. Other studies in Hong Kong [7] and Malaysia [8] reported that only one patient developed autoantibodies.

The pathogenesis of erythrocyte autoantibody formation following transfusion is not well understood. However, clinical evidence of autoimmune haemolytic anaemia has been seen with high amounts of RBC-associated IgG [21]. It was 
also suggested that alloantibody binding to the RBCs could lead to conformational changes of the antigenic epitope that ultimately stimulates production of autoantibodies [22]. It is possible that certain people are genetic responders who have an increased tendency to develop RBC autoantibodies and the tendency toward autoantibody formation could reflect an overall dysfunction of the immune system [23].

In this study there was a significant association of splenectomy with alloimmunization and autoantibodies ( $p=0.03,0.001$ respectively). In agreement with our study, Singer et al. and Sylvia et al. observed that Asian patients with splenectomy had a higher rate of alloimmunization compared with patients who did not have splenectomy $(p=0.06)$.

Also our results were supported by Wiener et al., [24] who revealed that significant elevations in RBCbound IgG were seen in thalassaemia patients and it was more abundant in splenectomized than nonsplenectomized subjects. They found that the absence of a spleen may further enhance the immune response to the infused foreign antigens which are not effectively filtered. In contrast, Noor Haslina et al. $[8,21]$ reported that in Malaysia despite a higher rate of patients with splenectomy none of them had alloantibodies and only one patient had autoantibodies.

In the present study there was no association between alloantibodies, autoantibodies and age at start of transfusion. Similarly, in Malaysian studies Noor Haslina $[8,21]$ found that there was no association between alloantibodies, autoantibodies and age at start of transfusion ( $p=0.5, p=0.8$ respectively).

In our study there was a significant association between groups of $\beta$-thalassaemia patients $(\beta$-thalassaemia major vs. sickle cell- $\beta$-thalassaemia; $\beta$-thalassaemia intermedia vs. sickle cell- $\beta$-thalassaemia) regarding allo- antibodies and also $(\beta$-thalassaemia major vs. $\beta$-thalassaemia intermedia; $\beta$-thalassaemia intermedia vs. sickle cell- $\beta$-thalassaemia) regarding autoantibodies. A vulnerable immune status of the recipient may predispose to an altered or increased immune response to various antigens. This aspect of immune status has never been explored in our patients, and needs to be looked into. This agrees with Fluit et al. [25] who found that some antigen-negative patients may not produce antibodies at all or may form only one antibody despite exposure to antigen-positive cells. Other patients may have serological findings of a clinically significant alloantibody without evidence of a haemolytic transfusion reaction, and this agrees also with Sylvia et al. who reported that with the growing knowledge base of the immune effects of current blood transfusion and limited data on immune status of thalassaemia patients, a large study addressing the complex interaction of these factors is needed.

In conclusion, alloimmunization to minor erythrocyte antigens and erythrocyte autoantibodies of variable clinical significance are frequent findings in transfusion-dependent $\beta$-thalassaemia patients. The overall frequency of alloantibody and autoantibody formation in our patients is $11.3 \%$ and $28.8 \%$ respectively. The most common alloantibodies are anti-K (Kell system), anti-E and anti-C (Rhesus system). There is a significant association between absence of the spleen and the presence of alloimmunization and autoantibody formation. The difference in the RBC antigen profile between donors and recipients together with splenectomy in this study likely contributes to these phenomena.

We recommend obtaining an RBC antigen phenotype for all thalassaemia patients who are started on transfusions and providing universal leukodepleted blood matched for antigens of the ABO, Kell and Rh system. Recruitment of Egyptian blood bank donors can increase the availability of compatible blood for beta thalassaemia patients.

\section{Acknowledgments}

This work was supported by the Department of Clinical and Chemical Pathology at the National Research Centre (NRC), Paediatric Department of the National Research Centre and New Children's Hospital, Cairo University, Egypt.

\section{References}

1. Rund D, Rachmilewitz E. Beta-thalassemia. NEJM 2005; 353: 1135-46.

2. Higgs DR, Thein SL, Woods WG. The molecular pathology of the thalassaemias. In: Weatherall DJ, Clegg B (eds). The Thalassaemia Syndromes. $4^{\text {th }}$ ed. Blackwell, Oxford 2001; 133-91.

3. Cunningham MJ, Macklin EA, Neufeld EJ, Cohen AR. Complications of beta-thalassemia major in North America. Blood 2004; 104: 34-39.

4. Old JM, Olivieri NF, Thein SL. Diagnosis and management of thalassaemia. In: Weatherall DJ, Clegg B (eds). The Thalassaemia Syndromes. $4^{\text {th }}$ ed. Blackwell, Oxford 2001; 630-85.

5. Karnon J, Zeuner D, Brown J, Ades AE, Wonke B, Modell B. Lifetime treatment costs of beta thalassemia major. Clin Lab Haematol 1999; 21: 377-85.

6. Ameen R, Al-Shemmari S, Al-Humood S, Chowdhury RI, Al-Eyoadi O, Al-Bashir A. RBC alloimmunization and autoimmunization among transfusion dependent Arab thalassemia patients. Transfusion 2003; 43: 1604-10.

7. Ho HK, lam CK, Chan GC. Alloimmunization in Hong Kong Southern Chinese transfusion - dependent thalassemia patients. Blood 2001; 97: 3999-4000.

8. Noor Haslina MN, Ariffin N, Hayati LL, Rosline H. Red cell immunization in multiply transfused Malay thalassemia patients. Southeast Asian J Trop Med Public Health 2006; 37: 1015-20.

9. Karimi M, Nikrooz P, Kashef S, Jamalian N, Davatolhagh Z. RBC alloimmunization in blood transfusion dependent 
beta thalassemia patients in Southern Iran. Int J Lab Hematol 2007; 29: 321-6.

10. Wang LY, Liang HC, Liu HC, et al. Alloimmunization among patients with transfusion dependent thalassemia in Taiwan. Transfusion Medicine 2006; 16: 200-3.

11. Blumberg N, Ross K, Avila E, Peck K. Should chronic transfusion be matched for antigens other than $\mathrm{ABO}$ and Rho(D)? Vox Sang 1984; 47: 205-8.

12. Singer ST, Wu V, Mignacca R, Kuypers FA, Morel P, Vichinsky EP. Alloimmunization and erythrocyte autoimmunization in transfusion dependent thalassemia patients of predominantly Asian descent. Blood 2000; 96: 3369-73.

13. Gader AG, Al Ghumlas AK, AL-Momen AK. Transfusion medicine in developing country-alloantibodies to red blood cells in multi-transfused patients in Saudi Arbia. Transfus Apher Sci 2008; 39: 199-204

14. Sirchia G, Zanella A, Parravicini A, Morelati F, Rebulla P, Masera G. Red cell alloantibodies in thalassemia major. Results of an Italian cooperative study. Transfusion 1985; 25: 110-2.

15. Spanos T, Karageorga M, Ladis V, Peristeri J, Hatziliami A, Kattamis C. Red cell alloantibodies in patients with thalassemia. Vox Sang 1990; 58: 50-5.

16. Taher A, Isma'eel H, Cappellini MD. Thalassemia intermedia: revisited. Blood Cells Mol Dis 2006; 37: 12-20.

17. Grady RW, Akbar AN, Giardina PJ, Hilgartner MW, de Sousa M. Disproportionate Lymphoid cell subsets in thalassemia major. The relative contributions of transfusion and splenectomy. Br J Haematol 1985; 59: 713-24.

18. Hodge G, Lloyd JV, Hodge S, Story C, Han P. Functional Lymphocyte immunophenotypes observed in thalassemia and hemophilia patients receiving current blood product preparations. Br J Haematol 1999; 105: 817-25.

19. Blajchman MA. Immunomodulatory effects of allogenic blood transfusion: clinical manifestations and mechanisms. Vox Sang 1998; 74: 315-9.

20. Ghio M, Contini P, Mazzei C, et al. Soluble HLA class I, HLA class II and Fas ligand and in blood components: a possible key to explain the immunomodulatory effects of allogeneic blood transfusions. Blood 1999; 93: 1770-7.

21. Noor Haslina MN, Ariffin N, Llluni HI, Rosline H. Red cell autoantibodies among thalassemia patients in Hospital University Sains Malaysia. Singapore Med J 2007; 48: 922-5.

22. Adani R, Sorenson S, Shinar E, Lande W, Rachmilewitz E, Schrier SL. Characterization and comparison of the red blood cell membrane damage in severe human alpha and beta thalassemia. Blood 1992; 79: 1058-63.

23. Castellino SM, Combs MR, Zimmerman SA, Issitt PD, Ware RE. Erythrocyte autoantibodies in pediatric with sickle cell disease receiving transfusion therapy: frequency, characteristics and significance. Br J Haematol 1999; 104: 189-94.

24. Wiener E, Wanachiwanawin W, Kotipan K, Fucharoen S, Wasi P, Wickramasinghe S. Erythroblast and erythrocyte bound antibodies in alpha and beta thalassemia syndromes. Transfus Med 1991; 1: 229-38.

25. Fluit CR, Kunst VA, Drenthe-Schonk AM. Incidence of red cell antibodies after multiple blood transfusions. Transfusion 1990; 30: 532-5. 